\title{
A Dwarfing Gene sdI-d (Dee-geo-woo-gen dwarf) on Lodging Resistance and Related Traits in Rice
}

Mukunda Bhattarai ${ }^{1}$, Misa Kamimukai ${ }^{1}$, Birendra Bahadur Rana ${ }^{2}$, Hiroki Oue ${ }^{1}$, Shinji Matsumura ${ }^{3}$ and Masayuki Murai $^{4 @}$

${ }^{1}$ United Graduate School of Agricultural Sciences, Ehime University, Matsuyama, Ehime, Japan; HO: MB: mukundab_7@yahoo.com; MK: s17dre10@s.kochi-u.ac.jp; BBR: bitu.deep25@gmail.com HO:oue@agr.ehime-u.ac.jp

${ }^{2}$ Nepal Agricultural Research Council, National Potato Research Program, Khumaltar, Lalitpur, Nepal ${ }^{3}$ Faculty of Agriculture, Kagawa University, Miki, Kagawa, Japan; matsumura.shinji@kagawa-u.ac.jp ${ }^{4}$ Faculty of Agriculture and Marine Science, Kochi University, Otsu-200, Monobe, Nankoku, Kochi, Japan. @: muraim@kochi-u.ac.jp

Received 20 November, 2020, Revised 25 December, 2020, Accepted 14 February, 2021, Published 30 April, 2021

Scientific Editors: Ujjawal Kr. S. Kushwaha, Jiban Shrestha, Krishna Hari Ghimire, Hari Bahadur KC

Copyright $(0) 2021$ NARC. Permits unrestricted use, distribution and reproduction in any medium provided the original work is properly cited.

The authors declare that there is no conflict of interest.

\section{ABSTRACT}

A dwarfing allele at the $s d l$ locus on chromosome 1 in rice, $s d l-d$, has been playing important role for developing lodging-resistant and high-yielding indica varieties IR8 and IR36. The dominant allele SD1 for long culm at the locus is differentiated into SD1-in and SDI-ja that are harbored in indica and japonica subspecies, respectively. The $s d 1-d$ of IR36 was substituted with SD1-in or SD1-ja by 17 backcrosses with IR36, and two isogenic tall lines were developed by using an indica variety IR5867 and a japonica one 'Koshihikari' as donors, which were denoted by "5867-36" and "Koshi-36", respectively. The present study was conducted to examine the effect of dwarfing gene $s d l-d$ on lodging resistance and related traits, compared with SDI-in and SDI-ja. Two isogenic lines and IR36 were cultivated in the field of the Faculty of Agriculture and Marine Science, Kochi University, Japan during 2017. Regarding index of lodging $(\mathrm{g} \cdot \mathrm{cm} / \mathrm{g}$ $\times 100$ ), genotypes were in the order: 5867-36 (97.4) > Koshi-36 (74.1) > IR36 (46.0) on the 21st-day after $80 \%$-heading, and they were in the same order on 10th-day after $80 \%$-heading. The 4 th-panicle length $(\mathrm{cm})$ was in the order: 5867-36 (118.7) > Koshi-36 (97.6) > IR36 (78.6). Similarly, the 4th-top weight (g) was in the order: 5867-36 (12.2) > Koshi-36 (10.2) > IR36 (9.6). The highest breaking strength (g) was recorded in IR36 (1649) followed by 5867-36 (1493) whereas the lowest breaking strength (g) was recorded in Koshi-36 (1360). Consequently, it is inferred that $s d l-d$ enhances lodging resistance due to the decreases in the length and weight above the 4th-internode as well as the increase of breaking strength. The effect of SD1-in on lodging resistance is lower than that of SDI-ja.

Keywords: Dwarfing allele, Lodging, Rice, $s d 1-d$, SD1-in, SD1-ja

\section{सारांश}

धानको बोटलाई होचो गराउने $s d l-d$ एलएली क्रोमोंजोम नम्बर $?$ हो र जुन यो $s d l-d$ एलएली गुण भयका आइ आर ८ र आइ आर ३६ जातले धैरै उत्पादन दिने र धानको बोटे नढल्ने जातीय विशेषता भएका जातले महत्त्वपूर्ण भुमिका खेलिरहेको छन् । यो डोमीनान्ट एलएली (ठुलो) $S D 1$ अग्लो धानको बोट हुने गुण भयको क्रमस दुई बटा छुट्टा छुट्टै आइसोजेनिक लाईन SDI-in (इन्डीका) र SDI-ja (जापोनिका) बाट तयार परियको थियो। यो सानो $s d 1$-d एलएली गुण भयको आइ आर ३६ धानको जातसित आइ आर ५८६७ लाई क्रमस १७ पटक क्रसिंग गरि बनाईएको आइसोजेनिक लाईन SDI-in (इन्डिका) र आइ आर ३६ सित कोसिहिकारी जापोनिका जातसित क्रमस १७ पटक क्रसिंग गरि बनाईएको आइसोजेनिक लाईन SD1-ja जापोनिका को विकास गरियको थियो र जसको नामाकरण क्रमस "ध८६७-३६" (इन्डिका) 
₹ “कोशी-३६" (जापोनिका) गरियको थियो | जुन यस अध्ययनमा $s d l-d$ एलएलीलाई धानको बोटे नढल्ने र यससंग सम्बंधित जातीय विशेषता गुण भयका यी दुइ बटा आइसोजेनिक लाईनसित तुलना गरियको थियो। यि दुई आइसोजेनिक लाईन र आइ आर ३६ धानको जातलाई २०७३ सालमा Faculty of Agriculture and Marine Science, Kochi University जापानमा लगाईएको थियो। यि सबै ८०\% धानको बाला निस्कियको २१औं दिन र १०औं दिनमा गरियको आनुसंधान थियो | जुन् बराबर आनुपातमा ढलेको थियो र क्रमस यो सुत्र प्रयोग (ए X बि/ सी X९००) गर्दा यिनिहारुमा सबैभन्दा धैरै ढल्लनेमा ५८६७-३६ (९७.४), कम ढल्लनेमा कोशी-३६ (७४.१), एककम कम ढल्लनेमा आइ आर ३६ (४६.०) पाईयको थियो | चौथो इन्टरनोडबाट बालाको टुप्पोसम्मको लम्बाई (से. मि.) पहिलोमा ५८६७-३६ (१९८.७), दोस्रोमा कोशी-३६ (९७.६) छ भने तेस्रोमा आइ आर ३६ (७८.६) पाईयको थियो | चौथो इन्टरनोडबाट बालाको टुप्पोसम्मको तौल (ग्राम) पहिलोमा ५८६७-३६ (१२.२) दोस्रोमा कोशी-३६ (१०.२) छ भने तेस्रोमा आइ आर ३६ (९.६) थियो। सबै भंन्दा कम ढल्ने (बलियो) धानकोबोट आइ आर ३६ (३६८०) दोस्रोमा ५८६७-३६ (१४९३) हो भने तेस्रोमा कोशी-३६ (३३६०) थियो। त्यसकारण, माथिको परिछ्युणबाट यो निश्चित गर्न सकिन्छकी $s d l-d$ एलएल्लीले धानको बोटलाई ढल्नबाट बचाऊछ र धानको चौथो इन्टरनोडबाट बालाको टुप्पोसम्मको बोटे होचो र बोटको तौल घटाई धानकोबोटेलाई बलियो बनाई ढल्नबाट बचाउनको लागि यो $s d 1-d$ एलएलीले प्रमुख भुमिका खेल्ने गर्ढछ। यि दुइ SDI-in र SD1-ja आइसोजेनिक लाईनसित तुलना गर्दा SD1-in को (५८६७-३६) कमढल्छ भने SD1-ja (कोशी-३६) बढीढल्छ।

\section{INTRODUCTION}

The short-culm and lodging-resistant indica rice (Oryza sativa $\mathrm{L}$., $2 \mathrm{n}=2 \mathrm{x}=24$ ) varieties such as IR8, IR36 and IR72, which harbor $s d l-d$ gene on chromosome 1 originating from the Taiwanese variety 'Dee-geo-woo-gen', are widely cultivated in Southeast Asia (De Datta et al 1968, Pang et al 1999). According to Murai et al $(1995,2002 \mathrm{a}, 2002 \mathrm{~b}), s d l-d$ reduced culm length by 25.7 to $32.2 \mathrm{~cm}$ (27 to $37 \%$ ) on the genetic background of the japonica variety Taichung 65, under various seven environmental conditions involving different fertilizer levels and years, and distant experimental sites in Japan. The wild type allele SDI encodes a gibberellin biosynthetic enzyme GA20 oxidase (GA20ox-2) that catalyzes late steps of gibberellin biosynthesis, while $s d l-d$ includes the deletion of $383 \mathrm{bp}$ between the two sites of the exon 1 and 2, resulting in the loss of the enzymatic function (Ashikari et al 2002, Monna et al 2002, Spielmeyar et al 2002). The dominant allele SD1 at the locus is differentiated into SD1-in and SD1-ja which is harbored in indica and japonica subspecies, respectively (Murai et al 2011). The effect of elongating culm was higher in the former allele than in the latter one, which could be one of the causes of inter-sub-specific difference in height (Murai et al 2011). Non-synonymous single-nucleotide polymorphism between SD1-in and SD1-ja was detected at the two sites in the exon 1 and 3 of the $s d l$ locus (Murai et al 2011, Asano et al 2011). According to Murai et al (2011), the $s d 1$ - $d$ of IR36 was substituted with $S D 1$-in or $S D 1$-ja by backcrossing with IR36 recurrently, and two tall isogenic lines regarding the respective dominant alleles were developed.

The lodging in the rice cultivation by transplanting can be classified into the breaking and bending types (Hitaka 1969, Yagi 1983). The former type of lodging often causes yield loss and deterioration of grain quality, resulting from reduction of photosynthesis by disturbing canopy structure, prevention of translocating water and nutrient elements from roots to leaves, and viviparity (Hitaka et al 1969), Seko (1962) devised the index of lodging, viz. the ratio of the moment (weight $\times$ length) above a basal internode to the breaking strength at the internode, and demonstrated its utility to evaluate the lodging resistance of a maturing rice plant. This index has been applied in several studies (Matsuzaki et al 1970 and 1972, Ichii and Hada 1983, Yagi 1983, Ookawa and Ishihara 1992, Amano et al 1993). Lodging resistance in paddy field is lowest at about 20-25 days after heading in general, because most of the starch stored in culms and leaf sheaths is utilized for grain filling until this time; thereafter, the breaking strength becomes higher due to re-accumulation of starch and other substances into the basal internodes (Sato 1957, Seko 1962, Matsuda et al 1983, Ichii and Hada 1983, Yagi 1983).

Murai et al (2004) investigate the effect of $s d l-d$ on lodging resistance on the genetic background of Taichung 65 , and obtained the results that $s d l-d$ enhances lodging resistance, reducing the value of the index of lodging, due to the two main factors, viz. 1) to reduce the length from the 4th internode to 
panicle top, and 2) to increase the braking strength at the internode. However, such investigation regarding the effect of $s d l-d$ has not been performed on the genetic background of an indica variety.

In the present study, the two tall isogenic lines and IR36 were grown in an experimental paddy field. The index of lodging, its three components, viz. the length from the 4th internode to panicle top, the total weight of panicle, leaves and internodes above the internode, and the braking strength at the internode, the number of leaving leaf sheaths on the internode were measured for the three lines/variety. The measurements were performed on 10 and 21 days after $80 \%$-heading. On the basis of the results obtained, the effects of $s d 1-d$ on lodging resistance and related traits, compared with the SDI-in and $S D 1-j a$, were examined on the common genetic background of IR36. Furthermore, the effects of SD1-in and SD1-ja were compared mutually.

\section{MATERIALS AND METHODS}

\section{Two tall isogenic lines}

The tall isogenic lines possessing SD1-in was developed by the following way (Murai et al 2011). An indica variety IR5867 carrying SDI-in was crossed with IR36. An $\mathrm{F}_{1}$ plant $(S D 1$-in/sdl-d) was backcrossed with IR36. Among $\mathrm{B}_{1} \mathrm{~F}_{1}$ plants (SD1-in/sdl-d and $\left.s d 1-d / s d 1-d\right)$, a tall (SD1-in /sdl-d) plant was backcrossed with IR36. Similarly, backcrossing and selecting tall plant were repeated to $\mathrm{B}_{17} \mathrm{~F}_{1}$ generation. Among $\mathrm{B}_{17} \mathrm{~F}_{2}$ plants, a tall (SDI-in/SDI-in) plant was selected. From $\mathrm{B}_{17} \mathrm{~F}_{3}$ to $\mathrm{B}_{17} \mathrm{~F}_{4}$ generations, non-segregation regarding plant height and other traits was ascertained, and the SDI-in isogenic line denoted by "5867-36" was completed. The SD1-ja isogenic line denoted by "Koshi-36" was completed by the same procedure as that in 5867-36 using a japonica variety 'Koshihikari' as the donor of SDl-ja.

\section{Cultivation in Experimental Field}

Seeds were sterilized with hot water of 62 to $55^{\circ} \mathrm{C}$ for 15 minutes for sterilization, to control blast, bakanae disease, grain rot, rice leaf tip nematode, etc. On $21^{\text {st }}$ April 2017, sterilized seeds were sown on plastic trays filled with granulated soil containing $\mathrm{N}, \mathrm{P}_{2} \mathrm{O}_{5}$ and $\mathrm{K}_{2} \mathrm{O}$ and being adjusted at $\mathrm{pH} 4.5$. Seedlings were grown at $25^{\circ} \mathrm{C}$ for 5 days, and then at $21^{\circ} \mathrm{C}$ for 7 days in a natural-light type growth chamber. Twelve-day old seedling were transplanted at a spacing of $30 \mathrm{~cm} \times 15 \mathrm{~cm}\left(22.2 \mathrm{hills} / \mathrm{m}^{2}\right)$ with two seedlings per hill to an experimental field of the Faculty of Agriculture and Marine Science, Kochi University, Nankoku, Japan $\left(33^{\circ} 35^{\prime} \mathrm{N}\right)$, on $3^{\text {rd }}$ May. The field trial for the two tall isogeneic lines and IR36 was conducted by the randomized complete block design with three replications. Each plot comprised 29 hills $\times 6$ rows (174 hills).

On $14^{\text {th }}$ April 2017, just before plowing, an ordinary chemical fertilizer was applied as basal dressing at the rate of $2.67 \mathrm{~g} / \mathrm{m}^{2}$ for each of $\mathrm{N}, \mathrm{P}_{2} \mathrm{O}_{5}$ and $\mathrm{K}_{2} \mathrm{O}$. Top-dressing was performed 62 and 64 days before $80 \%$ heading for the two tall isogenic lines and IR36, respectively, at the rate of 5.33, 4.19 and 4.95 $\mathrm{g} / \mathrm{m}^{2}$ for $\mathrm{N}, \mathrm{P}_{2} \mathrm{O}_{5}$ and $\mathrm{K}_{2} \mathrm{O}$, respectively, with a slow release and coated fertilizer ECOLONG ${ }^{\circledR}$ 413-180 type (about $3 \%$ of each nutrient element is readily available), manufactured by JCAME AGRI Co., Ltd. Accordingly, the total amount of the chemical fertilizers applied was at a rate of 8.00, 6.86 and 7.62 $\mathrm{g} / \mathrm{m}^{2}$ for $\mathrm{N}, \mathrm{P}_{2} \mathrm{O}_{5}$ and $\mathrm{K}_{2} \mathrm{O}$, respectively (Table 1 ).

Table 1. Chemical fertilizers applied in the experimental field

\begin{tabular}{|c|c|c|c|c|}
\hline Way of apply & $\begin{array}{l}\text { Chemical fertilizers } \\
\text { applied }\end{array}$ & $\mathbf{N}\left(\mathrm{g} / \mathrm{m}^{2}\right)$ & $\mathbf{P}_{2} \mathrm{O}_{5} \quad\left(\mathrm{~g} / \mathrm{m}^{2}\right)$ & $\mathrm{K}_{2} \mathrm{O}\left(\mathrm{g} / \mathrm{m}^{2}\right)$ \\
\hline Basal dressing & Ordinary chemical fertilizer & 2.67 & 2.67 & 2.67 \\
\hline Top-dressing & ECOLONG $^{\circledR} 413-180$ type & 5.33 & 4.19 & 4.95 \\
\hline Total & & 8.00 & 6.86 & 7.62 \\
\hline
\end{tabular}


Seko (1962) observed that the breaking occurred mainly at the $4^{\text {th }}$ or $5^{\text {th }}$ internode in lodged rice plants, when its length was higher than $6 \mathrm{~cm}$. The length of $4^{\text {th }}$ internode of three genotypes 5867-36, Koshi-36 and IR36 was recorded 12.9, 6.5 and $3.9 \mathrm{~cm}$, respectively whereas that of the $5^{\text {th }}$ internode was $7.0,3.9$ and $2.3 \mathrm{~cm}$, respectively (Table 3 ). The $5^{\text {th }}$ internode length of IR36 was too short to measure its breaking strength by the fulcrum distance of $3.0 \mathrm{~cm}$. On the other hand, the $4^{\text {th }}$ internode lengths of the lines-variety were above $3.0 \mathrm{~cm}$, indicating that their breaking strengths at this internode were commonly measurable. Accordingly, the index of lodging was applied for the $4^{\text {th }}$ internode. The $4^{\text {th }}$-panicle length (the length from the base of the $4^{\text {th }}$ internode to panicle top) (a), the $4^{\text {th }}$-top weight (the total fresh weight of panicle, leaves and the $1^{\text {st }}$ to $4^{\text {th }}$ internodes) (b), and the breaking strength at the $4^{\text {th }}$ internode (c) were measured for the longest culm in each hill. The Breaking Strength Meter for Cereal Culm TR-S (Fujiwara Seisakusho Co., Ltd., Tokyo, Japan) was used for the measurement (Figure 1). The breaking strength at the central site of the $4^{\text {th }}$ internode with leaf sheaths was measured by placing it on the twined hook with its midrib downward to be drawn by the single hook, because the thickness from the midrib to the opposite side was greater (hard to break) than the thickness across it (easy to break). The index of lodging was calculated by the formula $100 \times$ $\mathrm{ab} / \mathrm{c}$. We used the fulcrum distance of $3.0 \mathrm{~cm}$ instead of that of $5.0 \mathrm{~cm}$ (Table 3). Measurements were performed at the two times of ripening, viz. 10 days and 21 days after $80 \%$-heading. At each time, the longest culm in each of 24 hills was sampled from each replication (72 hills in total) in the three lines/variety, and the traits were measured. The lengths of panicle and the $1^{\text {st }}$ to $5^{\text {th }}$ internodes were measured for each of the culms. The culm length from the ground level was measured for the highest culm in each hill for ten hills per plot (30 hills per line/variety) at maturity.

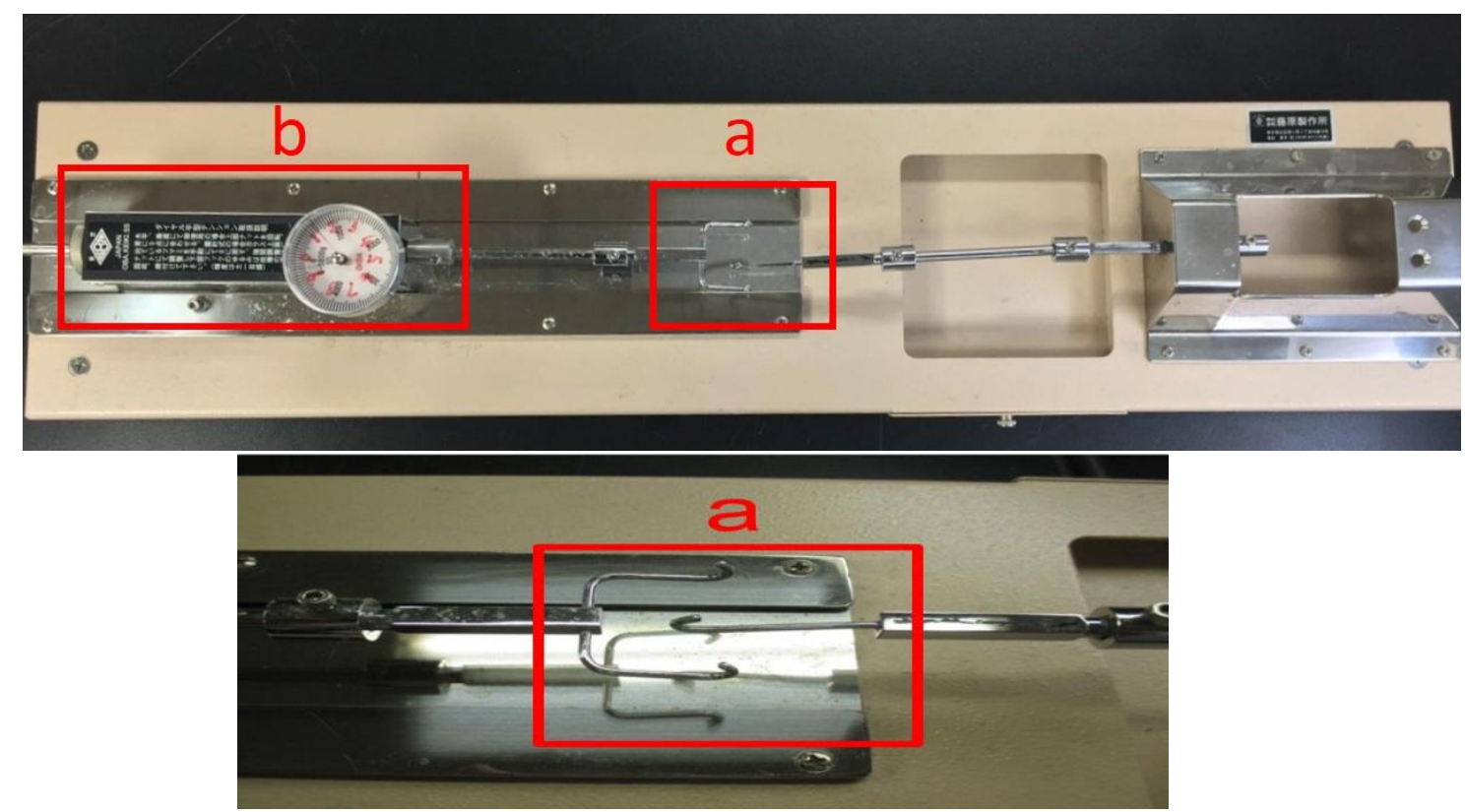

Figure 1. Breaking Strength Meter for Cereal Culm. The two fulcrums at the distance of $3.0 \mathrm{~cm}$ were set on the twined hook (a) which is connected to the spring balance (b). The center of the fourth internode was placed between the two fulcrums, and was drawn with the single hook rightward.

\section{RESULTS}

As shown in Table 2, the genotypes were headed in between 97-99 days, whereas maturity was ranged from 121 to 130 days, indicating little genetic difference among them in crop duration.

Table 2. Days to $80 \%$ heading and maturity of tested genotypes

\begin{tabular}{lcccc}
\hline \multirow{2}{*}{ Traits } & \multicolumn{3}{c}{ Allele } \\
\cline { 2 - 4 } & \multicolumn{1}{c}{ SD1in } & SD1-ja & sd1-d \\
\cline { 2 - 4 } & $\mathbf{5 8 6 7 - 3 6}$ & Koshi-36 & IR36 \\
\hline Days to 80\% heading & 97 & 97 & 99 \\
\hline Days to maturity & 121 & 124 & 130 \\
\hline
\end{tabular}


Table 3 shows the lengths of culm, the $1^{\text {st }}$ to $5^{\text {th }}$ internodes and panicle in 5867-36, Koshi-36 and IR36. In culm length, the genotypes were in the order of 5867-36 $(101.9 \mathrm{~cm})>\operatorname{Koshi}-36(80.1 \mathrm{~cm})>$ IR36 $(60.0 \mathrm{~cm})$, where " $>$ " indicates that the former is statistically higher than the later at $5 \%$ level of significance. Accordingly, $s d l-d$ reduced culm length by 41.9 and $20.1 \mathrm{~cm}$, compared with $S D 1$-in and SD1-ja, respectively. The effect of elongating culm was higher in the former allele than in the latter one. Regarding the length of $1^{\text {st }}$ to $5^{\text {th }}$ internodes, 5867-36 has the longest internodes (by 4.7 to $11.1 \mathrm{~cm}$ than IR36). On the other hand, Koshi-36 has longer internodes then IR36 by 1.6 to $5.8 \mathrm{~cm}$ in the 1 st to 5 th internodes.

Panicle length was in the order of 5867-36 $(24 \mathrm{~cm})>$ Koshi-36 $(22.5 \mathrm{~cm}) \geq \operatorname{IR} 36(21.8 \mathrm{~cm})$, where " $\geq$ " indicates that the former is higher than the latter but not statistically significant. The variation in this trait was smaller than that in culm length, since the panicles of 5867-36 and Koshi-36 were 110 and $103 \%$ longer than IR36 while the culm length was 170 and 133\% longer than IR36, respectively.

Table 3. Lengths of culm, the $1^{\text {st }}$ to $5^{\text {th }}$ internodes and panicles in tested genotypes

Trait

Allele

\begin{tabular}{cccc}
\hline SD1-in & & SD1-ja & sd1-d \\
\hline $\mathbf{5 8 6 7 - 3 6}$ & Koshi-36 & IR36
\end{tabular}

Culm length

101.9 a $(170)$

$80.1 \quad b$

(133)

1R36

Internode length

\begin{tabular}{cccccccccc}
\hline 1st & 38.2 & $\mathrm{a}$ & $(122)$ & 35.6 & $\mathrm{~b}$ & $(114)$ & 31.3 & $\mathrm{c}$ & 0.6 \\
\hline 2nd & 25.3 & $\mathrm{a}$ & $(179)$ & 19.6 & $\mathrm{~b}$ & $(139)$ & 14.2 & $\mathrm{c}$ & 0.3 \\
\hline 3rd & 17.9 & $\mathrm{a}$ & $(241)$ & 13 & $\mathrm{~b}$ & $(178)$ & 7.5 & $\mathrm{c}$ & 1.1 \\
\hline 4th & 12.9 & $\mathrm{a}$ & $(336)$ & 6.5 & $\mathrm{~b}$ & $(170)$ & 3.9 & $\mathrm{c}$ & 0.4 \\
\hline 5th & 7.0 & $\mathrm{a}$ & $(305)$ & 3.9 & $\mathrm{~b}$ & $(170)$ & 2.3 & $\mathrm{c}$ & 0.8 \\
\hline Panicle length & 24.0 & $\mathrm{a}$ & $(110)$ & 22.5 & $\mathrm{~b}$ & $(103)$ & 21.8 & $\mathrm{~b}$ & 1.0 \\
\hline
\end{tabular}

Values followed by the same letter within each trait are not significantly different at the $5 \%$ level, determined by LSDs in the table. (): Percentage of 5867-36 or Koshi-36 to IR36.

Values followed by the same letter within each trait are not significantly different at the $5 \%$ level, determined by LSDs in the table. Figure in parenthesis is the percentage (\%) of lines (5867-36 or Koshi-36) to variety (IR36).

Table 4. Analysis of variance for lodging index, its three components and number of living leaf sheaths of 5867-36, Koshi-36 and IR36 on the $10^{\text {th }}$ and $21^{\text {st }}$ days after $80 \%$ heading, in which numerals show F-values

\begin{tabular}{|c|c|c|c|c|c|c|}
\hline Traits & $\begin{array}{r}\text { Lines- } \\
\text { variety } \\
\text { (A) }\end{array}$ & & $\begin{array}{c}\text { Time after } 80 \% \\
\text { heading (B) }\end{array}$ & & $\begin{array}{r}\text { Interaction } \\
\text { A X B }\end{array}$ & \\
\hline Lodging index $(\mathrm{g} \cdot \mathrm{cm} / \mathrm{g})$ & 154.61 & $* *$ & 102.70 & $* *$ & 1.53 & \\
\hline $4^{\text {th }}$-panicle length $(\mathrm{cm})$ & 535.83 & $* *$ & 1.80 & & 1.20 & \\
\hline 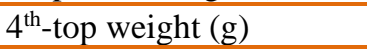 & 210.96 & $* *$ & 29.56 & $* *$ & 3.71 & \\
\hline Breaking strength $(\mathrm{g})$ & 8.68 & $* *$ & 66.32 & $* *$ & 1.47 & \\
\hline No. of living leaf sheaths & 3.24 & & 54.74 & $* *$ & 10.37 & $* *$ \\
\hline
\end{tabular}

Degrees of freedom for lines-variety, times of measurement, the interaction and error are 2, 1, 2 and 10, respectively.

$*$, ** Significant at the $5 \%$ and $1 \%$ levels, respectively. 
Table 5. Lodging index and its three components at the $4^{\text {th }}$ internode in 5867-36, Koshi-36 and IR36 on the $10^{\text {th }}$ and $21^{\text {st }}$ day after $80 \%$ heading

\begin{tabular}{|c|c|c|c|c|c|c|c|c|c|c|}
\hline Traits & $\begin{array}{c}\text { Time of } \\
\text { measurement }\end{array}$ & \multicolumn{3}{|c|}{ 5867-36 } & \multicolumn{3}{|c|}{ Koshi-36 } & \multicolumn{2}{|c|}{ IR36 } & $\begin{array}{l}\text { LSD } \\
(5 \%)\end{array}$ \\
\hline \multirow[t]{2}{*}{$\begin{array}{l}\text { Index of lodging ( } \mathrm{g} . \\
\mathrm{cm} / \mathrm{g} \text { ) }\end{array}$} & 10 day & 73.1 & $\mathrm{~b}$ & $(253)$ & 48.0 & $\mathrm{c}$ & $(166)$ & 28.9 & d & \multirow{2}{*}{8.6} \\
\hline & 21 day & 97.4 & $\mathrm{a}$ & (212) & 74.1 & $\mathrm{~b}$ & $(161)$ & 46.0 & c & \\
\hline \multirow[t]{2}{*}{$\begin{array}{l}\text { 4th-panicle length } \\
(\mathrm{cm})\end{array}$} & 10 day & 115.3 & $\mathrm{a}$ & $(147)$ & 97.5 & $\mathrm{~b}$ & $(125)$ & 78.2 & c & \multirow[t]{2}{*}{3.7} \\
\hline & 21 day & 118.7 & $\mathrm{a}$ & (151) & 97.6 & $\mathrm{~b}$ & $(124)$ & 78.6 & $\mathrm{c}$ & \\
\hline \multirow[t]{2}{*}{ 4th-top weight (g) } & 10 day & 11.9 & $\mathrm{a}$ & $(140)$ & 9.7 & $\mathrm{c}$ & $(115)$ & 8.5 & $\mathrm{~d}$ & \multirow{2}{*}{0.5} \\
\hline & 21 day & 12.2 & $\mathrm{a}$ & $(127)$ & 10.2 & $\mathrm{~b}$ & $(106)$ & 9.6 & $\mathrm{c}$ & \\
\hline \multirow[t]{2}{*}{ Breaking strength $(\mathrm{g})$} & 10 day & 1876 & $\mathrm{bc}$ & (82) & 1969 & $\mathrm{~b}$ & $(86)$ & 2290 & $\mathrm{a}$ & \multirow{2}{*}{258} \\
\hline & 21 day & 1493 & de & $(91)$ & 1360 & $\mathrm{e}$ & $(82)$ & 1649 & $\mathrm{~cd}$ & \\
\hline \multirow[t]{2}{*}{$\begin{array}{l}\text { No. of living leaf } \\
\text { sheaths }\end{array}$} & 10 day & 1.08 & $\mathrm{~b}$ & (68) & 1.51 & $\mathrm{a}$ & $(96)$ & 1.58 & $\mathrm{a}$ & \multirow[t]{2}{*}{0.27} \\
\hline & 21 day & 0.97 & $\mathrm{~b}$ & (138) & 0.97 & $\mathrm{~b}$ & (138) & 0.71 & $\mathrm{c}$ & \\
\hline
\end{tabular}

Values followed by the same letter within each trait are not significantly different at the 5\% significant level as determined by the LSDs in the table. Figures in parenthesis are the percentage of lines to variety.

\section{Index of lodging and its related traits}

Table 4 shows analysis of variance for the index of lodging and the related traits of 5867-36, Koshi-36 and IR 36 on $10^{\text {th }}$ and $21^{\text {st }}$ days after $80 \%$ heading. The effect of lines/variety was statistically significant in the four traits except number of living leaf sheath. The effect of the times of measurement was significant in the four traits except $4^{\text {th }}$-panicle length. The interaction between the lines/variety and the times of measurement was significant only in the number of living leaf sheaths.

Table 5 shows the lodging index, its three components and number of living leaf sheath in three genotypes 5867-36, Koshi-36 and IR36 on the $10^{\text {th }}$ and $21^{\text {st }}$ days after $80 \%$-heading. Regarding lodging index, the genotypes were in the order of 5867-36>Koshi-36>IR36, which was identical between two times of measurement. In each line/variety, this trait was higher on the $21^{\text {st }}$ days than on the $10^{\text {th }}$ days after $80 \%$-heading. Regarding $4^{\text {th }}$-panicle length, the lines/variety were in order of 5867-36> Koshi-36 $>$ IR36 in both the times of measurement. In each genotype, significant difference was not noticed in this trait for times of measurement. Regarding $4^{\text {th }}$-top weight, the genotypes were in the order of 5867-36> Koshi-36 > IR36, which was identical for both the times of measurement. In each genotype, this trait was higher at the later time of measurement ( $21^{\text {st }}$ day after $80 \%$ heading) than at the former one $\left(10^{\text {th }}\right.$ day), although being not significant statistically in the case of 5867-36. Regarding breaking strength, the genotypes were in the order of IR36 > Koshi-36 $\geq 5867-36$ at the former $\left(10^{\text {th }}\right.$ day) time of measurement. Significant difference was not noticed between the two lines but IR36 was the highest. At the later ( $21^{\text {st }}$ day) time of measurement, this trait was in the order of IR36 $\geq 5867-36 \geq$ Koshi-36 (IR36 $>$ Koshi-36). In each line/variety, this trait was higher at the former time of measurement than at the latter one. Regarding number of living leaf sheaths, the lines/variety was in the order of IR36 $\geq$ Koshi-36 > 5867-36 at the former time of measurement. At the later time of measurement, this trait was in the order of 5867-36 $\geq$ Koshi-36 > IR36. In each genotype, this trait was higher at the former time of measurement than at the later time of measurement, although the difference was not statistically significant in the case of 5867-36.

\section{DISCUSSION}

Breaking strength decreased from the $10^{\text {th }}$ day to $21^{\text {st }}$ day after $80 \%$ heading (Table 5), which is consistent with the previous studies (Sato 1957, Seko 1962, Matsuda et al 1983, Ichii and Hada 1983, Yagi 1983). During this period, $4^{\text {th }}$-top weight increased, resulting in the increase of lodging index. The 
decrease in number of living leaf sheaths seems to have accelerated it, because a lower internode is supported against breaking with living leaf sheaths covering the internode (Hitaka 1969, Matsuzaki et al 1972, Miyasaka and Takaya 1982, Takaya and Miyasaka 1983, Ookawa and Ishihara 1992, Amano et al 1993). The significant effects of both the lines/variety and times of measurement, and the non-significant interactive effect regarding lodging index (Table 4) suggest that the lodging resistance of the genotypes were able to be evaluated consistently at the two times of measurement. It is inferred that $s d 1-d$ decreased lodging index by 112 and $61 \%$ compared with SDI-in and SDI-ja, respectively, at the later time of measurement (Table 5). Lodging index was positively correlated with $4^{\text {th }}$-panicle length and $4^{\text {th }}$-top weight among the six combinations of three genotypes and two times of measurement $(\mathrm{r}=0.883$ and 0.925 , significant at the 5 and $1 \%$ levels, respectively). Accordingly, lodging index was principally associated with $4^{\text {th }}$-panicle length that is almost parallel to culm length. Secondly, 5867-36 and Koshi-36 were higher by 27 and 6\%, respectively, in $4^{\text {th }}$-top weight than IR36 at the later time of measurement, indicating that this trait was related to the enhancement of lodging resistance by $s d l-d$. Correlation coefficient between index of lodging and breaking strength was negative but not significant at the 5\% level $(\mathrm{r}=-0.750)$. The reason of this lower correlation is considered as follows: the genotypes were in the order of 5867-36 > Koshi-36 > IR36 in breaking strength in each time of measurement; in breaking strength, however, Koshi-36 was not significantly different from 5867-36 even though IR36 was the highest identically at the two times of measurement. Correlation coefficient between number of living leaf sheaths and breaking strength was positive but not significant at $5 \%$ level $(\mathrm{r}=0.801)$. Accordingly, this trait seems to have contributed breaking strength but its effect was supportive and not decisive; for example, IR36 had the highest breaking strength but the fewest living leaf sheaths at the later time of measurement.

Genotype 5867-36 had the higher value of lodging index compared with IR36 on the $21^{\text {st }}$ day after $80 \%$ heading, due to the higher $4^{\text {th }}$-panicle length, the higher $4^{\text {th }}$-top weight and the lower breaking strength, in which the extents of their effects on the lodging index were in this order 5867-36 > Koshi-36 > IR36 (Table 5). Therefore, it is inferred that $s d l-d$ drastically enhances lodging resistance compared with SD1-in. Serious lodging was observed in 5867-36 at the late stage of maturity, while no lodging was observed in IR36. Consequently, it is indispensable to use $s d l-d$ in breeding programs of indica rice. Koshi-36 had the intermediate value of lodging index between IR36 and 5867-36 on the $21^{\text {st }}$ day after $80 \%$ heading, due to the intermediate values in both $4^{\text {th }}$-panicle length and $4^{\text {th }}$-top weight, and the lowest breaking strength. A similar result was obtained using the $s d l-d$ isogenic line of Taichung 65 and japonica. Taichung 65 carrying $S D 1-j a$, although the effect of $s d l-d$ on enhancing lodging resistance compared with SDI-ja seems to be amplified on the genetic background of this variety (Murai et al 2004). The bending of culms was observed at maturity in Koshi-36, although being not serious. Hence, it is inferred that the effect of $S D 1$-ja on lodging resistance is intermediate between those of $s d 1-d$ and $S D 1-i n$. This is consistent with the fact that only a few officially registered varieties carrying $s d 1-d$ are cultivated in Japan (Tabuchi et al 2000) while japonica varieties carrying SD1-ja such as Koshihikari predominate over there (Rice Stable Supply Support Organization, 2020).

\section{REFERENCES}

Amano T, Q Zhu, Y Wang, N Inou and H. Tanaka 1993. Case studies on high yields of paddy rice in Jiangsu province, China. II. Analysis of characters related to lodging. Jpn. J. Crop. Sci. 62: 275-281. https://agriknowledge.affrc.go.jp/RN/2030502455.pdf

Asano K, M Yamasaki, S Takuno, K Miura, S Katagiri, T Ito, K Doi, J Wu, K Ebana, T Matsumoto, H Innan, H Kitano, M Ashikari and M Matsuoka. 2011. Artificial selection for a green revolution gene during japonica rice domestication, Proc. Natl. Acad. Sci. USA, 108; pp. DOI: https://doi.org/10.1073/pnas.1019490108 
Ashikari M, A Sasaki, M Ueguchi-Tanaka, H Itoh, A Nishimura, S Datta, K Ishiyama, T Saito, M Kobayashi, GS Khush, H Kitano and M Matsuoka. 2002. Loss-of-function of a rice gibberellin biosynthetic gene, GA20 oxidase (GA20ox-2), led to the rice 'Green revolution', Breed. Sci., 52: 143-150.

DOI: https://doi.org/10.1270/jsbbs.52.143

De Datta S K, AC Tauro and SN Balaoing. 1968. Effects of plant type and Nitrogen level on the growth characteristics and grain yield of indica rice in the tropics. Agron. J. 60: 643-647.

DOI: https://doi.org/10.2134/agronj1968.00021962006000060017x

Hitaka H. 1969. Studies on the lodging of rice plants. J. Agric. Res. Quart. 4 (3): 1-6.

Ichii M and Hada K. 1983. Application of raton to test of Agronomic characters in rice breeding II. The relationship between raton ability and lodging resistance. Jpn. J. Breed 33:251-258.

Matsuda T, H Kawahara and N Chonan. 1983. Histological studies on breaking resistance of lower internodes in rice culm. IV. The roles of each tissue of internode and leaf sheath in breaking resistance. Jpn. J. Crop Sci. 52: 355-361. DOI: https://doi.org/10.1626/jcs.52.355

Matsuzaki A, S Matsushima, T Tomita and N Jojima. 1970. Analysis of yield-determining process and its application to year-prediction and culture improvement of rice. XCVII. Effects of nitrogen depletion at different at stages of the plant type and lodging resistance of rice plants after heading. Proc. Crop Sci. Soc. Jpn. 39: 330-336. DOI: https://doi.org/10.1626/jcs.39.330

Matsuzaki A, S Matsushima, T Tomita and E Katsuki. 1972. Analysis of yield-determining process and its application to year-prediction and culture improvement of rice. CIX. Effects of nitrogen top-dressing at gull heading stage on lodging resistance, root activity, yield and kernel quality. Proc. Crop Sci. Soc. Jpn. 41: 139-146. DOI: https://doi.org/10.1626/jcs.41.139

Miyasaka A and T Takaya. 1983. Prevention of lodging of rice plants under direct sowing culture on well-drained paddy field. I. Varietal differences in lodging resistance under dense sowing. Jpn. J. Crop Sci. Soc. 51: 360-368. DOI: https://doi.org/10.1626/jcs.51.360

Monna L, N Kitazawa, R Yoshino, J Suzuki, H Masuda, Y Maehara, M Tanji, M Sato, S Nasu and Y Minobe. 2002. Positional cloning of rice semi dwarfing gene, sd-1: Rice "Green revolution gene" encodes a mutant enzyme involved in gibberellin synthesis”, DNA Res. 9; pp. 11-17.

DOI: https://doi.org/10.1093/dnares/9.1.11

Murai M, H Nagano K, Onishi A, Ogino N, Ichikawa H, B KC and Y Sano. 2011. Differentiation in wild-type allele of the $s d l$ locus concerning culm length between indica and Japonica subspecies of Oryza sativa (rice). Hereditas 148: 1-7. DOI: https://doi.org/10.1111/j.1601-5223.2010.02168.x

Murai M, Komazaki T and Sato S. 2004. Effects of $s d 1$ and Url (Undulate rachis-1) on lodging resistance and its related traits in rice Breed. Sci. 54: 333-340. DOI: https://doi.org/10.1270/jsbbs.54.333

Murai M, I Takamure, S Sato, T Tokutome and Y Sato. 2002a. Effects of the dwarfing gene originating from "Dee-geo-woo-gen" on yield and its related traits in rice Breed Sci. 52: 95-100.

DOI: https://doi.org/10.1270/jsbbs.52.95

Murai M, N Shinbashi, S Sato, K Sato, H Araki and M Ehara. 1995. Effects of a dwarfing gene from Dee-geo-woo-gen on culm and Internode lengths, and its response to fertilizer in rice. Breed. Sci. 45:7-14. DOI: https://doi.org/10.1270/jsbbs1951.45.7

Murai M, S Sato, A Nagayama and N Ihashi 2002b. Effects of a major gene $U r l$ characterized by undulation of rachis branches on yield and its related traits in rice. Breed. Sci. 52: 299-307.

DOI: https://doi.org/10.1270/jsbbs.52.299

Ookawa T and K Ishihara. 1992. Varietal differences of physical characteristics of the culm related to lodging resistance in paddy rice. Jpn. J. Crop Sci. Soc. 61: 419-425. DOI: https://doi.org/10.1626/jcs.61.419

Peng S, KG Cassman, SS Virmani, J Sheehy and GS Khush. 1999. Yield potential trends of tropical rice since the release of IR8 and the challenge of increasing rice yield potential. Crop Sci. 39: 1552-1559.

DOI: https://doi.org/10.2135/cropsci1999.3961552x

Rice Stable Supply Support Organization (June 2020). Available at: < https://www.komenet.jp/_qa/kome_hinshu/sakutsuke.html> [Accessed on 11th August 2020].

Sato K. 1957. Studies on the starch contained in the tissues of rice plants. IV. Starch content in culm related to lodging (preliminary report). Proc. Crop Sci. Jpn. 26: 19.

Seko H. 1962. Studies on lodging in rice plants. Bull Kyusyu Agr. Exp. Sta 7:419-499.

Spielmeyer W, MH Ellis and PM Chandler. 2002. "Semi dwarf (sd-1), "green revolution" rice, contains a defective gibberellin 20-oxidase gene”, Proc. Natl. Acad. Sci. USA, 99; pp. 9043-9048.

DOI: https://doi.org/10.1073/pnas.132266399

Tabuchi H, N Hashimoto, A Takeuchi, T Terao and Y Fukuta. 2000. Genetic analysis of semi dwarfism of the japonica rice. 
Takaya T and A Miyasaka. 1982. Prevention of lodging of rice plants under direct sowing culture on well-drained paddy field. II. Transition of characters related to lodging resistance after the heading. Jpn. J. Crop Sci. Soc. 52: 7-14. DOI: https://doi.org/10.1626/jcs.52.7

Yagi T. 1983. Studies on breeding for culm stiffness in rice. 1 varietal differences in culm stiffiness and its related traits. Jpn. J. Breed. 33: 411- 422. DOI: https://doi.org/10.1270/jsbbs1951.33.411।

$|1|-----|------| \mid$ 